\title{
THE RELATIONSHIP BETWEEN OLD AND NEW TESTAMENT: A STUDY ON CONTEMPORARY DEBATE OF METHODOLOGY OF THE OLD TESTAMENT THEOLOGY
}

\author{
Made Astika \\ sttjaffraymakassar@yahoo.co.id
}

\begin{abstract}
From the beginning of the discipline, biblical theologians have differed in their understandings of an accredited basis, task, and method for doing biblical theology.

In accordance with the existing problems, the purpose of writing this paper are: In accordance with the existingproblems, the main motive and purposes of writing this research are: First of all, to show the continuity of the relation between the Old Testament and New Testament. Secondly, to explain methodology in doing Old Testament Theology through the investigation of historical and biblical understanding. Finally, to call and challenge every leader and church congregation together to analyze methodology of biblical theology in order to develop the proper methodology in doing Old Testament Theology.

The conclutions are: The relationship between the Old Covenant and the New can be presented as follows: God has only one covenant of grace, and only one eternal people - in which a person obtains a share through faith in Christ alone, the Covenant Head and the Adam of the new humanity. Herein lies the unity of God's eternal plan of salvation, and of the Word as His special revelation to man. It must be put in mind that the God of the Old Testament is also the God of the New Testament. It should be clear that the God and Father of the Lord Jesus Christ is the same God who created man and woman, who established marriage, and who redeemed Israel through the Exodus, foreshadowing the redemption of believers through Christ. The Lord Jesus' concept of God as Father contained a truth not characteristic of the Old Testament, but yet not negating any Old Testament teaching about God.
\end{abstract}

Key words: Relationship, Methodology, Old Testament Theology 


\section{INTRODUCTION}

There is no doubt that the early writers considered the Old Testament writings to be initiated as a single work by God himself, as surely if he had written each letter upon a stone with his own finger. As for the New Testament, it is the compliment of the Old. Without the New Testament, the Old is merely a collection of historical or religious writings. The old could not complete the work, for it was incomplete, being alone. The two joined however now becomes one new book that the Christian Church declares to be the canon of biblical truth, that is, the standard by which all other truth is to be measured. Unfortunately many biblical theologians, however, reject this orthodox understanding of the Bible's inspiration and its canonical authority. Some profess a new dogma that the Bible is only the product of Israel's experiences and human thoughts about God.

Bruce K. Waltke wrote in his book, "From the beginning of the discipline, biblical theologians have differed in their understandings of an accredited basis, task, and method for doing biblical theology." The problem of Old Testament theology has become very largely a problem of methodology, and the need to find a suitable arrangement by means of which the contents of the Old Testament can be presented theologically. Phyllis Trible explains, "Biblical theologians ... have never agreed on the definition, method, organization, subject matter, point of view, or purpose of their enterprise." 2

Based on this fact, the writer invites readers to look the relationship of two Testaments on the title "The Relationship Between Old And New Testament: A Study On Contemporary Debate Of Methodology Of Old Testament Theology," with hope that this small paper will give an input on developing the understanding of Old Testament Theology.

${ }^{1}$ Bruce K. Waltke, An Old Testament Theology (Grand Rapids, Michigan: Zondervan, 2007), 9

${ }^{2}$ Phyllis Trible, "Overture for a Feminist Biblical Theology," in The Flowering of Old Testament Theology: A Reader in Twentieth-Century Old Testament Theology, 1930 - 1990, ed. Ben C. Ollenburger, Elmer A. Martens, and Gerhard F. Hasel (Winona Lake, Ind.: Eisenbrauns, 1992), 451. 


\section{THE NATURE OF OLD TESTAMENT THEOLOGY}

"In many and various ways God spoke of old to our fathers by the prophets; but in these last days he has spoken to us by a Son, whom he appointed the heir of all things, through whom also he created the world" (Heb. 1:1). With these words the writer of the letter to the Hebrews expressed in brief yet most fundamental and significant language a primary concept of the formative ideas and structural pattern of biblical theology.

As is clear from the name, OT theology is certain of theology. It is the study of theology that has the Old Testament as its primary subject matter. It would seem that little else need be said since it is common knowledge what the Old Testament is and every reader of the Bible knows what theology is.

There is diversity of opinion about how one's understanding of the Old Testament theology is affected when it is applied to the understanding of the nature of Old Testament theology. Is it correct to say that "Old Testament theology" is merely that branch of theology that has the Old Testament as its subject matter?

For the sake of clarity in understanding the nature of Old Testament theology, it is important to come to some agreement on the meaning of Old Testament theology.

\section{The Meaning of Old Testament Theology}

Since not everyone is agreed on what Old Testament theology is or should be, followed are several definitions of Old Testament theology that was adopted from scholars. The purpose of this is to give an input on building description of the meaning and task of Old Testament Theology.

According to Sailhamer, it is important to understand the meaning of theology before come to define the meaning of Old Testament Theology. He declared, theology is the restatement and explication of God's revelation, the Bible. It intends to state what should be heard as normative for the faith and practice of the Christian believer. He defines what the Old Testament theology is. He offered, Old Testament theology is the study and presentation of what is revealed in the Old Testament.

\footnotetext{
${ }^{3}$ Chester K. Lehman, Nature and Method of Biblical Theology, available from http://www.bibleviews.com/ot-chl.html, accessed on March, 25 2009
} 
The word "revelation" is usually taken as a term which describes an act of God. God, has revealed himself in the Bible. Old Testament theology is concerned with that revelation of God's will given in the Old Testament. $^{4}$

Simply can be said that the Old Testament theology is what God has revealed about Himself in the Old Testament. The system of Old Testament theology takes the various truths that the Old Testament books teach us about God and presents them in an organized fashion. God's revelation of Himself begins in Genesis 1:1: "In the beginning God created the heavens and the earth." That is a presupposition that all believers accept by faith and is based on the study of God throughout all the Scripture from Genesis to Revelation. Since the Bible is true in all of its aspects, then all of it, as it comes from God, is true and eternal. It never passes away, nor will it ever deny itself in any of its parts. ${ }^{5}$

Specifically, Payne comment, a biblical theology that is true and real, that represents the Bible in a way consistent with its own teaching. It may be defined as the Biblical history of divine redemption. It means that biblical theology is historical. It deals with objective affairs and ideas, through a long succession of time period. Then, it is divine, deals with divinity. The basic truth in biblical theology is the reality of God, actively communicating His will in history. Redemptive deals with God's purpose in history which is to bring men back to Himself through Christ. $^{6}$

The Old Testament testifies to its own divine nature, that is, the biblical texts are an inspired narrative configuration of God's revelation in history. It means that the starting point is the Word-Revelation in its final form of canonical texts, and not human reason. ${ }^{7}$

The nature of the theology of the Old Testament is not merely a theology which is in conformity with the whole Bible, but it is that theology described and contained in the Bible (subjective genitive) and consciously joined from era to era as the whole previously antecedent context becomes the base for the theology which followed in each era. Its

\footnotetext{
${ }^{4}$ John H. Sailhamer, Introduction to Old Testament Theology: A Canonical Approach (Grand Rapids, Michigan: Zondervan Publishing House, 1995), 21.

${ }^{5}$ What is Old Testament Theology? Available from http://www.gotquestions.org/OldTestament-theology.html, accessed on March $20^{\text {th }} 2009$.

${ }^{6}$ J. Barton Payne, The Theology of the Older Testament (Grand Rapids, Michigan: Zondervan Publishing House, 1962), 15-17.

${ }^{7}$ Han Young Lee, From History to Narrative Hermeneutics (New York: Peter Lang Publishing Inc., 2004), 192.
} 
structure is historically arranged and its content is exegetically controlled. Its center and unified conceptuality is to be found in the textual descriptions, explanations, and connections. ${ }^{8}$

\section{The History of Old Testament Theology}

Historically the church confesses that God reveals his nature and mind and inspires human agents to present them in infallible Scriptures and that his Spirit illuminates the meaning of the Scriptures to the faithful. Brevard S. Childs adopts and defends a self-consciously confessional approach: "The role of the Bible is not being understood simply as a cultural expression of ancient peoples, but as a testimony pointing beyond itself to divine reality to which it bears witness. . . . Such an approach to the Bible is obviously confessional. Yet the Enlightenment's alternative proposal that was to confine the Bible solely to the arena of human experience is just as much a philosophical commitment." 9

The Old Testament was appreciated by its contemporaries as a revelation from God, and it was used by its own later writers as a theological source book (Ps. 78; Jer. 26:18; Ezra 7:10; Neh. 8:1-8). Jesus Christ regularly spoke from it as the basis and description of His own teaching and work (cf. Matt. 5:17 etc). The apostolic circle, including the New Testament writers, studied it as a prophetic of the Savior (Acts 3:24). There is no record, however, of the biblical theology as an organized study.

The theology of the Old Testament is still a young branch of studies, indeed it is one of the youngest of the disciplines of Biblical studies. It would not take long to relate the basic outline of its history, which dates from the end of the eighteenth and the beginning of the nineteenth century. ${ }^{10}$

Paul R House has an opinion that the beginnings of the discipline of Biblical Theology are commonly traced to March $30^{\text {th }} 1787$, when Johann P. Gabler delivered an address entitled "An Oration on the Proper Distinction Between Biblical and Dogmatic Theology and the Specific

\footnotetext{
${ }^{8}$ Walter C. Kaiser, Jr., Toward an Old Testament Theology (Grand Rapids, Michigan: Zondervan Publishing House, 1978), 9.

${ }^{9}$ Brevard S. Childs, Biblical Theology: A Proposal (Minneapolis: Fortress, 2002), 12.

${ }^{10}$ Gerhard von Rad, Old Testament Theology, vol. I (New York: Harper \& Row Publisher, 1962), v.
} 
Objectives of Each" at the university of Altdorf, Germany. "l Gabler began by sharply distinguishing Biblical Theology which he characterized as a historical discipline (e gnere historico) from dogmatic theology which he described as didactic in nature. ${ }^{12}$ Before this time biblical theology had been subsumed under systematic theology (dogmatics). Gabler declared that biblical theology differs from dogmatics in it origin and purpose.

According to Gabler, the origin of biblical theology lies in the Bible itself, while dogmatic theology stems from individual theologians with prior philosophical and ecclesiological commitments. Biblical theology's purpose is to set forth what the biblical writers actually believed. Dogmatic's theology's goal is to perpetuate a pre-established point of view. ${ }^{13}$

The history of Biblical Theology throughout the nineteenth century and well into the early twentieth century shows clearly the effect of the emancipation of the discipline from its dependency on ecclesiastical doctrine. B. S. Childs mentioned at least three effects. ${ }^{14}$

First of all, with few exceptions the field divided into two separate disciplines of Old and New Testament theologies, which at the first continued to retain the term biblical theology.

Secondly, along with the concern to maintain the independence of Biblical Theology from dogmatic theology, there went a search for a new philosophical framework by which to integrate the biblical material over and above a straightforward historical reading.

Thirdly, among many critical scholars there was a growing assumption that Biblical Theology as an academic discipline was largely anachronistic and was an unfortunate vestige from a past era.

In his historical survey of major trends in the history of Biblical and Old Testament theology form their beginnings to the revival of Old Testament theology after World War I, Gerhard F. Hasel divided the

\footnotetext{
${ }^{1 l}$ Paul R. House, Old Testament Theology (Downers Grove, Illinois: InterVarsity Press, 1998), 15.

${ }^{12}$ Brevard S. Childs, Biblical Theology of the Old and New Testaments (London, Great Britain: SCM Press Lt., 1996), 4.

${ }^{13}$ Paul R. House, Old Testament Theology (Downers Grove, Illinois: InterVarsity Press, 1998), 16.

${ }^{14}$ Brevard S. Childs, Biblical Theology of the Old and New Testaments (London, Great Britain: SCM Press Lt., 1996), 5-6.
} 
journey of the development of Old Testament theology into four periods. $^{15}$

First, from the Reformation to the Enlightenment. The Protestant principle of "sola scriptura" which became the battle cry of the Reformation against scholastic theology and ecclesiastical tradition, the source for the subsequent development of Biblical theology. The Protestant Reformation re-established two principles that were prerequisites to the development of Biblical theology. The first was the principle of "the analogy of Scripture." It denied the right of the church, the Pope, or any other human agency to establish the interpretation of Scripture. Interpretation, according to this principle, can come only from other Scripture. The second was the principle of "the literal sense." This, in turn, eliminated the allegorizing that had dominated the Middle Ages; and it made possible a revival of interest in the truly historical development of revelation. Exegesis now came into its own, based upon the original languages of Scripture. ${ }^{16}$

Second, the age of Enlightenment. In the age of enlightenment a totally new approach for the study of the Bible was developed. Biblical theology now became a rival of dogmatic and turn into a completely separate and independent discipline.

Third, from the Enlightenment to dialectical theology. The subsequent development reveals that the new historical discipline succumbed to and was dominated by various philosophical systems, then experienced the challenge of conservative Biblical scholarship, and finally was eclipsed by the "history-of-religions" approach. ${ }^{17}$ Belief in God's communication had been overshadowed by a rising cloud of historicism. The "historicists," as a school of interpretation, limited Scripture to a history of religion: the Bible became a product of human, evolutionary development, and not supernatural revelation. ${ }^{18}$

Fourth, the revival of Old Testament theology. In the 1922 came the first clear sign of reviving interest in Old Testament theology with the

\footnotetext{
${ }^{15}$ Gerhard F. Hasel, Old Testament Theology: Basic Issues in the Current Debate (Grand rapids, Michigan: William B. Eerdman Publishing Company, 2001), 11-27.

${ }^{16} \mathrm{~J}$. Barton Payne, The Theology of the Older Testament (Grand Rapids, Michigan: Zondervan Publishing House, 1962), 26.

${ }^{17}$ Gerhard F. Hasel, Old Testament Theology: Basic Issues in the Current Debate (Grand rapids, Michigan: William B. Eerdman Publishing Company, 2001), 20.

${ }^{18} \mathrm{~J}$. Barton Payne, The Theology of the Older Testament (Grand Rapids, Michigan: Zondervan Publishing House, 1962), 29.
} 
publication of E. Konig's Theologie des AT. ${ }^{19}$ Eichrodt began the "golden age" of Old Testament theology with a well-deserved attack on the reigning historicism of his day. ${ }^{20}$

\section{METHODOLOGY OF THE OLD TESTAMENT THEOLOGY}

The issues related to the question of methodology in Old Testament theology are complex. It relates to the question of whether Old Testament theology is purely descriptive and historical or whether it is a normative or and theological enterprise. The distinction between what a text meant and what a text means is at the core of most fundamental problem of Old Testament theology, because "what it meant" is not simply discovering the meaning of the biblical text within its own canonical biblical context; it is historical reconstruction. ${ }^{21}$

Scholars analyze the text using many and varied techniques, some some ancient and some post modern, some borrowed from other disciplines and some others developed from within. All of these are designed not to reach complete understanding, but rather to move that understanding a small step forward. ${ }^{22}$

\section{Methodology in Old Testament Theology}

Gerhard Hasel categorized the methodology in Old Testament theology as follows. ${ }^{23}$

First, the Dogmatic-Didactic Method. The traditional method of organizing OT theology is the approach borrowed from dogmatic (or systematic) theology and its division (for it loci) of God-Man-Salvation or Theology-Anthropology-Soteriology.

Second, the Genetic-Progressive Method. Chester K. Lehman defines the "method of Biblical theology" as one "determined in the main by the principle of historic progression." This is understood as "the

\footnotetext{
${ }^{19}$ Gerhard F. Hasel, Old Testament Theology: Basic Issues in the Current Debate (Grand rapids, Michigan: William B. Eerdman Publishing Company, 2001), 11-27.

${ }^{20}$ Walter C. Kaiser, Jr., Toward an Old Testament Theology (Grand Rapids, Michigan: Zondervan Publishing House, 1978), 5.

${ }^{21}$ Gerhard F. Hasel, Old Testament Theology: Basic Issues in the Current Debate (Grand rapids, Michigan: William B. Eerdman Publishing Company, 2001), 30-31.

${ }^{22}$ David Baker and Bill T. Arnold, The Face of Old Testament Studies: A Survey of Contemporary Approaches (Grand Rapids, Michigan: Baker Book House Company, 1999), 9.

${ }^{23}$ Gerhard F. Hasel, Old Testament Theology: Basic Issues in the Current Debate (Grand rapids, Michigan: William B. Eerdman Publishing Company, 2001), 39-1ll.
} 
unfolding of God's revelation as the Bible presents it." The historic progression of the unfolding revelation is evidenced in "periods or eras of divine revelation (which) are determined in strict agreement with the lines of cleavage drawn by revelation itself." More specifically this means that divine revelation centers in the several covenants made by God with Noah, Abraham, Moses, and through Christ, all of which manifest the "organic being" of the Bible and Scripture's "own anatomy."

Third, the Cross-Section Method. The cross-section approach was developed by W. Eichordt. He was able to achieve a cross-section approach through the world of OT thought by making the covenant the center of the OT. His aim is "to understand the realm of OT belief in its structural unity ... (and) to illuminate its profoundest meaning. The cross-section method, with Eichordt use of the covenant concept as the means whereby unity is achieved, is to some extent artificial, since the OT is less amenable to systematization than Eichordt suggest.

Fourth, the Topical Method. The topical method is distinguished from the dogmatic-didactic-method in its refusal to let outside categories be superimposed as a grid through which the OT materials and themes are read, ordered, and systematized. It also steers away from the cross-section method and its synthesis of the OT world thought. The topical method is used either in combination with a single or dual center of the OT or without an explicit thematic center. In short, the three major representatives of the topical approach in this decade differ vastly in (1) starting-points, (2) structures of their materials, (3) selection of topics, (4) sequence of presentation, (5) center of OT theology, (6) emphases and evaluation of OT materials, (7) consistency in their own individual structures.

Fifth, the Diachronic Method. The diachronic method for OT theology is dependent upon tradition-historical research which was developed in 1930's. The diachronic approach penetrates into the successive layers of the fixed text of the OT with the aim of unfolding "Israel's theological activity which is probably one of its most important and interesting ones, namely those ever new attempts to make the divine acts of salvation relevant for every new age and day - this ever new reaching-out to and avowal of God's acts which in the end made the old creedal statements grow into such enormous masses of tradition."

Sixth, the "Formation-of-Tradition Method. The formation-oftradition approach was proposed by the OT scholar Hartmut Gese. Gese insists the OT theology "must be understood essentially as an historical process of development. Only in this way does such a theology achieve 
unity, and only then can the question of its relationship to the New Testament be raised. In short, foe Gese "only tradition history ... can describe biblical theology... Tradition history can become the method of biblical theology because it goes beyond historical facts and religious phenomena and describes the living process forming tradition." The "formation-of-tradition" model of OT as conceived by Gese seeks to overcome the issue of the "center" of the Testaments through a process of tradition common to both Testaments. Douglas A. Knight states categorically that the "tradition-historical method cannot be used to explain the essential relationship between the Old Testament and the New Testament." The reason for this is that within th OT "this growth process reached an end in the various tradition complexes, books, and larger work; and in virtually this form they were eventually canonized."

Seven, the Thematic-Dialectical Method. W. Brueggmann has suggested that there is a new convergence in recent OT theology that in his view points to a resolution of the methodological stalemate. This convergence is evident in approaches to OT (and Biblical) theology that use a dialectical and thematic relationship. The convergence is evident in that each scholar uses dialectic; the divergence is equally evident in that each one employs a different dialectic.

Eighth, Recent "Critical" OT Theology Methods. Some scholars have recently attempted not to write OT theologies but to reflect about the future of the OT theology and argue for a renewal of "critical" approaches to OT theology. James Barr and John J. Collins, whose approaches will receive brief attention in what follows, share the perception that OT theology does not seem to have too bright a future. Barr stands in the scholarly tradition of solid modern historical criticism, rejecting historical views of inspiration and biblical authority.

Ninth, the "New Biblical Theology" Method. One of the most basic issues for Biblical scholarship and OT theology is the question of the relationship of the OT to the NT. Without doubt the one scholar who in our generation has pointed time and again to a "new biblical theology" that is Brevard Childs. He proposed a "new biblical theology" that is to overcome the dichotomy of "what it meant" and "what it means" so rigorously applied by modern criticism. Childs a "new biblical theology" claims to take seriously the canon of Scripture as its context. Childs' thesis that the canon of the Christian church is the most appropriate context from which to do Biblical Theology. A most significant corollary of this thesis is that in as much as the Biblical text in its canonical form is employed as the context for interpreting Scripture and doing Biblical 
theology, it amounts, to "a rejection of the (historical-critical) method that would imprison the Bible within a context of the historical past.

\section{Basic Proposals for Doing Old Testament Theology ${ }^{24}$}

The following are Hasel attempt to focus on unresolved crucial problems which are the center of the current crisis in Old Testament theology has revealed that there are basic inadequacies in the current methodologies and approaches.

According to Hasel, a productive way to proceed from here on appears to have to rest upon the following basic proposals for doing OT theology. First of all, biblical theology must be understood to be a historical theological discipline. This is to say that the Biblical theologian engaged in doing either Old or New Testament theology must claim as his task both to discover and describe what the text meant and also to explicate what it means for today. Second, if Biblical theology is understood to be a historical-theological discipline, it follows that its proper method must be both historical and theological from the startingpoint. A theology of the OT presupposes exegesis based upon sound principles and procedures. Exegesis, in turn, is in need of OT theology. Without OT theology the work of exegetical interpretation way easily become endangered by isolating individual texts from the whole. Third, the Biblical theologian engaged in OT theology has his subject indicated beforehand in as much as his endeavor is a theology of the Old Testament. It is founded exclusively on materials taken from the OT. The OT comes to him through the Christian church as part of the inspired Scriptures. Introduction to the OT seeks to throw light on the preliterary and literary stages and forms of the OT books by tracing their history of transmission and formation as well as the text-forms and the canonization of the OT. Fourth, the presentation of the theologies of the OT books, or groups of writings, will preferably not follow the order of the books in the canonical sequence, for this order, whether in the Hebrew canon or the LXX, etc., had apparently other than theological causes. Though admittedly difficult to fix, the date of origin of the books, group writings, or blocks of material within these writings may provide a guide for establishing the order of presentation of the various theologies. Fifth, an Old Testament theology not only seeks to know the

\footnotetext{
${ }^{24}$ Gerhard F. Hasel, Old Testament Theology: Basic Issues in the Current Debate (Grand rapids, Michigan: William B. Eerdman Publishing Company, 2001), 190-207.
} 
theology of the various books, or group of writings; it also attempts to draw together and present the major themes of the Old Testament. On principle, a theology of OT must tend toward themes, motifs, and concept and must be presented with all the variety and all the limitations imposed on them by the Old Testament itself. Sixth, as the Old Testament is interrogated for its theology, it answers first of all by yielding various theologies, namely those of the individual books and group writings, and then by yielding the theologies of the various longitudinal themes. But the name of our discipline as theology of the OT is not only concerned to present and explicate the variety of different theologies. The concept foreshadowed by the name of the discipline has one theology in view, namely the theology of the OT. The final aim of OT theology is to demonstrate whether or not there is an inner unity that binds together the various theologies and longitudinal themes, concepts, and motifs. Finally, the Biblical theologian understands OT theology as being more than the "theology of the Hebrew Bible." The name "theology of the Old Testament" implies the larger context of the Bible of which the New Testament is the other part. An integral OT theology must demonstrate its basic relationship to the NT or the NT theology.

\section{RELATIONSHIP BETWEEN OLD AND NEW TESTAMENT}

What is the precise relationship of the New Testament to the Old? Is one of the two Testaments more important than the other? Are there parts of the Old Testament which ought to be minimized in the teachings of the Christian church? Should the Ten Commandments be recited today or at least taught as a Christian standard?

These are just some of the theological and practical questions crucial for teachers of the Bible, which grow out of the basic issue of the relationship of the two Testaments. To some there is no 'issue', because both Testaments can be seen to have meaning when Christ is the key. To them the matter is expressed satisfactorily in the ancient couplet: 'The New is in the Old concealed; the Old is in the New revealed.' If this was good enough for Augustine, should it not be good enough for us? ${ }^{25}$

\footnotetext{
${ }^{25}$ Walter L. Liefeld, "Unity and Diversity in the Two Testaments," Christian Brethren Review, available from http://www.biblicalstudies.org.uk/pdf/cbr/unity_liefeld.pdf, accessed on March $27^{\text {th }}$ 2009.
} 
On the other hand, the very existence of the couplet testifies to the fact that from the church fathers on, Christians have recognized that there are two very different Testaments which need to be understood in proper relationship to each other. The approaches made to this relationship over the centuries have varied considerably from each other.

\section{Views of the Law in Relation to the New Testament ${ }^{26}$}

There are differences of opinion among Christian denominations as to what and how Biblical law applies in a Christian context. There are diverse views of the issues involved. Although Christianity by tradition affirms that the Five Books of Moses (the Pentateuch or Torah) is the inspired word of God, Christian tradition denies that all Mosaic Law applies directly to Christians. The differences are mainly as a result of attempts to harmonize biblical statements to the effect that the biblical law is eternal with New Testament statements that suggest that it does not now apply at all, or at least does not fully apply.

\section{Roman Catholic View}

The Roman Catholic view is summarized in The Catechism of the Catholic Church: Part 3, Life in Christ: Section 2, The Ten Commandments: "Teacher, what must I do ...?" as follows:

The Council of Trent teaches that the Ten Commandments are obligatory for Christians and that the justified man is still bound to keep them; the Second Vatican Council confirms: 'The bishops, successors of the apostles, receive from the Lord ... the mission of teaching all peoples, and of preaching the Gospel to every creature, so that all men may attain salvation through faith, Baptism and the observance of the Commandments.'

By his life and by his preaching Jesus attested to the permanent validity of the Decalogue.

\section{Lutheran View}

The view of the Lutheran Church is summarized in the Formula of Concord which declared (Article V): "We believe, teach, and confess that the distinction between the Law and the Gospel is to be maintained in

\footnotetext{
${ }^{26}$ Relationship between Old and New Testament available from http://en.wikipedia.org/wiki/Old testament, accessed on March $27^{\text {th }} 2009$.
} 
the Church with great diligence..." Martin Luther wrote: "Hence, whoever knows well this art of distinguishing between Law and Gospel, him place at the head and call him a doctor of Holy Scripture."

The distinction between Law and Gospel in the Lutheran view is that Law demands obedience to God's will, while Gospel refers to the promise of forgiveness of sins in the light of the person and work of Jesus Christ.

\section{Reformed Church View}

The Reformed view is similar to the Roman Catholic view. It holds that under the new covenant, the Mosaic Law fundamentally continues, but that parts of it have "expired" and are no longer applicable.

The Westminster Confession of Faith (1646) divides the Mosaic laws into three categories: moral, civil, and ceremonial. In the view of the Westminster divines, only the moral laws of the Mosaic Law, which include the Ten Commandments and the commands repeated in the New Testament, directly apply to Christians today. Ceremonial laws, in this view, include the regulations pertaining to ceremonial cleanliness, festivals, diet, and the Levitical priesthood. While the view affirms Sabbath like the Roman Catholic view, some advocates hold that the Commandment concerning Sabbath was redefined by Jesus (Matthew 12:1-13, Luke 13:10-17).

\section{The Anglican View}

The Anglican view is essentially the same as the Roman Catholic, and is neatly summarized in Article 7 of the Articles of Religion (the Thirty-Nine Articles): "Although the law given from God by Moses, as touching ceremonies and rites, do not bind Christian men, nor the civil precepts thereof ought of necessity to be received in any commonwealth; yet, notwithstanding, no Christian man whatsoever is free from the obedience of the commandments which are called moral."

\section{The Dispensational View}

The Dispensational view holds that under the new covenant, the Mosaic Law has fundamentally been terminated, or abolished, because, in this view, Scripture never describes the Law as divisible - it is one unit (James 2:10-11). Therefore, because portions of New Testament Scripture (such as Heb. 8:13) are understood in this view to annul at least parts of the Law, then the whole Law must be terminated. 
Furthermore, this view holds that the Mosaic laws and the penalties attached to the laws were limited to the particular historical and theological setting of the Old Testament, described in this view as a different "dispensation"; a stage of time in which God dealt with humanity in a fundamentally different way than he does now. We are now living in the "dispensation" of the church/grace, which is a "parenthesis" or "intercalation" in history that is outside of God's overarching plan for Israel, and thus the Law given to Israel doesn't now apply.

Dispensational believe to the double promise. Promise for the Israel and promise for the church. God has special purpose for the Israel and the church. They believe that promise was end when Israel rashly accepted the Law. ${ }^{27}$

\section{The New Covenant Theology View}

New Covenant Theology believes that God has maintained one eternal purpose in Christ which has been expressed through a multiplicity of distinct historical covenants; that prominent among these are those designated the Old Covenant (also known as the Mosaic or First Covenant) and the New Covenant; that the former, confined to the people of Israel alone, was established while that nation was assembled before Mt. Sinai and was later made obsolete through its fulfillment by the life and death of Jesus the Messiah; that it was comprised largely of shadows pointing ultimately to Jesus and His body, the Church; and that, therefore, the age in which it remained operative was at all times a period of immaturity as compared to the age of fulfillment which was inaugurated with Christ's first advent.

The Old Covenant, containing a single, unified law code, was a legal, conditional covenant requiring perfect and complete obedience of all those under it; that, on the one hand, it promised life to all who obeyed it, and, on the other hand, it pronounced a curse upon all its transgressors; that it, therefore, inescapably brought death to all who sought to be justified by it-not because of a deficiency in the law (itself "holy, just, and good"), but because of the sinful inability of those under its charge; and that, for this reason, it is variously described as a "killing letter", a "ministry of death", and a "ministry of condemnation"—its

\footnotetext{
${ }^{27}$ Han Young Lee, Old Testament Theology, Class Note (Yangpyeong, Seoul: ACTS, Spring Semester, 2009).
} 
distinct purpose being to illumine sin so as to make manifest the Israelites' and, by implication, all men's need for a redeemer.

In contrast to the Old Covenant, the New Covenant (by virtue of Christ's perfect obedience to the law, as well as His bearing of its curse) promises only blessing to all those who belong to it; and that this second covenant, the "everlasting covenant" enacted upon better promises, has thus brought to realization all that was anticipated in the covenants made with Abraham, Moses, and David.

Under the New Covenant, God's people, having entered the age of fulfillment, now stand as mature sons; that having been set free from the tutelage and bondage of the law code written upon tablets of stone, they have subsequently been placed under the Spirit's management-having the new and greater Lawgiver's own law now written upon their hearts.

The Covenant theology believed that Abraham covenant of promise is renewal of the former covenant. Its unconditional covenant was bound to be fulfillment. It's continuing from creation to the consummation. ${ }^{28}$ The Mosaic covenant of law definitely served to advance the purposes of redemption...It is stressed that the Law "was not given as a way of life ... but as a rule of living for people already in the covenant of Abraham and covered by the blood sacrifice... The law is not here proposed as a means of salvation but as a means by which Israel, already redeemed as a nation, might through obedience fulfill her proper destiny. ${ }^{29}$

\section{The Problem Of The Relationship}

In understanding of the Bible as a whole, all of the theological problems that come, inquiring into the inner unity of the manifold testimony of the Bible. Basic to whole question is not merely an articulation of the theological problem of the interrelatedness between the two Testaments but also an inquiry into the nature of this unity and disunity, whether it is one of language, thought-forms, or content. ${ }^{30}$

Both structurally and thematically the covenants of God are one. A covenantal unity characterizes God's dealings with men from creation to consummation. But the various covenants administered throughout

\footnotetext{
${ }^{28}$ Han Young Lee, Old Testament Theology, Class Note (Yangpyeong, Seoul: ACTS, Spring Semester, 2009).

${ }^{29}$ O. Palmer Robertson, The Christ of the Covenants (Phillipsburg, New Jersey: Presbyterian and Reformed Publishing Co., 1980), 215-216.

${ }^{30}$ Gerhard F. Hasel, Old Testament Theology: Basic Issues in the Current Debate (Grand rapids, Michigan: William B. Eerdman Publishing Company, 2001), 172.
} 
history do not appear as monotonous duplication of one another. Robertson mentions three basics structural distinctions have been suggested by various theologians with respect to covenental diversity: Pre-creation covenant/post-creation covenants; Covenant of works/covenant of grace; Old covenant/New covenant. All three of these distinctions deserve consideration. ${ }^{31}$

Pre-creation covenant between Father and Son has been designated variously as the "covenant of redemption," the "eternal covenant," the "counsel of peace," or the "counsel of redemption. The intention of God from eternity to redeem a people to himself certainly must be affirmed. Before the foundation of the world God set his covenantal love on his people.

The second distinction is about covenat of works/covenant of grace. The term "covenant of works" has been applied to God's relation to man prior to his fall into sin. This relationship has been characterized as a covenant of "works" in an effort to emphasize the testing period of Adam. If Adam should "work" peoperly, he would receive the blessings promised by God.

The phrase "covenant of grace" has been used to describe the relationship of God to his people subsequent to man's fall into sin. Since man became incapable of works suitable for meriting salvation, this period has been understood as being controlled primarily by the grace of God.

The third distinction is old covenant/new covenant. The bond of God with man before Christ may be called "old covenant" and the bond of God with man after Christ may be called "new covenant." The old covenant may be characterized as promise, as shadow, as prophecy; the new covenant may be characterized as fulfillment, as reality, as realization.

The complex nature of the interrelationship between the Testaments requires a multiplex approach. No single category, concept, or scheme can be expected to exhaust the varieties of interrelationships. ${ }^{32}$ Among the patterns of historical and theological

\footnotetext{
${ }^{31}$ O. Palmer Robertson, The Christ of the Covenants (Phillipsburg, New Jersey: Presbyterian and Reformed Publishing Co., 1980), 53-63.ting salvation, this

${ }^{32}$ In this respect, Gerhard Hasel agree with W. H. Schmidt, "Theologie des AT vor und nach Gerhard von Rad," in Verkundingung und Forschung (Beiheft zur EvT, 17, Munich: 1972), 24.
} 
relationships between the Testaments are the following, Hasel suggested. ${ }^{33}$

A common mark of both Testaments is the continuous history o God's people and the picture of God's dealings with mankind.

New emphasis has been put upon the connection between the Testaments on the basis of Scriptural quotations.

Among the interrelationships between the Testaments appears the common use of theological key term. Almost every key theological word of the New Testament is derived from some Hebrew word that had a long history of use and development in the Old Testament.

The interrelationship between the Testaments comes also to expression through the essential unity of major themes. Each of the major themes of the Old Testament has its correspondent in the New, and is in some way resumed and answered there. Such themes as rulership of God, people of God, exodus experience, election and covenant, judgment and salvation, etc., present themselves for immediate consideration. A guarded and circumspect use of typology is indispensable for an adequate methodology that attempts to come to grips with the historical context of the OT and its relationship to the NT. The category of promise/prediction and fulfillment elucidates another aspect of the interrelatedness of the Testaments.

Last but not least is the concept of salvation history that links the two Testaments together. Secular history and salvation history are not to be conceived as two separate realities. Particular historical events have a deeper significance, perceived through divine acts in human history. The course of salvation history was inaugurated for man after the fall and moved from Adam and all mankind through Abraham to Christ, and from him it moves to the goal of history, the final future consummation in glory.

If properly conceived, these multiple interrelationships between the Testaments may be considered to elucidate the unity of the Testaments without forcing uniformity upon the diverse Biblical witnesses. There is unity in diversity.

${ }^{33}$ Gerhard F. Hasel, Old Testament Theology: Basic Issues in the Current Debate (Grand rapids, Michigan: William B. Eerdman Publishing Company, 2001), 191-193. 


\section{CONCLUSION}

The relationship between the Old Covenant and the New can be presented as follows: God has only one covenant of grace, and only one eternal people - in which a person obtains a share through faith in Christ alone, the Covenant Head and the Adam of the new humanity. Herein lies the unity of God's eternal plan of salvation, and of the Word as His special revelation to man.

It must be put in mind that the God of the Old Testament is also the God of the New Testament. It should be clear that the God and Father of the Lord Jesus Christ is the same God who created man and woman, who established marriage, and who redeemed Israel through the Exodus, foreshadowing the redemption of believers through Christ. The Lord Jesus' concept of God as Father contained a truth not characteristic of the Old Testament, but yet not negating any Old Testament teaching about God.

The other fact is that both Testaments are the revealed Word of God. The past decades have seen an emphasis on the personal revelation of God with, in some quarters, a de-emphasis on 'propositional revelation' (objective statements). The former is commendable; the latter is to be lamented. ${ }^{34}$

Robertson concludes, the covenant structure of Scripture manifests a marvelous unity. God, in binding a people to himself, never changes. For this reason, the covenants of God relate organically to one another. From Adam to Christ, a unity of covenantal administration characterizes the history of God's dealing with his people. The divine covenants of Scripture are bound together not only by a structural unity. They manifest also a thematic unity. This unity of theme is the heart of the covenant as it relates God o his people. The heart of the covenant is the declaration that "God with us." 35

There is a diversity of contexts, a diversity of concepts and a diversity of applications of the Old Testament texts in the New Testament. Nevertheless there is a unity around the person of Christ.

\footnotetext{
${ }^{34}$ Walter L. Liefeld, "Unity and Diversity in the Two Testaments," Christian Brethren Review, available from http://www.biblicalstudies.org.uk/pdf/cbr/unity_liefeld.pdf, accessed on March $27^{\text {th }}$ 2009.

${ }^{35}$ O. Palmer Robertson, The Christ of the Covenants (Phillipsburg, New Jersey: Presbyterian and Reformed Publishing Co., 1980), 45.
} 
There is one God and Father and there is one eternal Son, the Servant Messiah. His coming and that of the Holy Spirit were promised in the Old Testament. The true people of God, both the Jewish 'remnant' and the largely Gentile church welcomed the fulfillment of God's promise. The Law and the Prophets were fulfilled. God remembered his oath and gave us a better covenant through the One who was his final Word.

\section{BIBLIOGRAPHY}

\section{Books}

Baker, David and Arnold, Bill T. The Face of Old Testament Studies: A Survey of Contemporary Approaches. Grand Rapids, Michigan: Baker Book House Company, 1999.

Bruce K., Waltke. An Old Testament Theology. Grand Rapids, Michigan: Zondervan, 2007.

Childs, Brevard S. Biblical Theology of the Old and New Testaments. London, Great Britain: SCM Press Lt., 1996.

Hasel, Gerhard F. Old Testament Theology: Basic Issues in the Current Debate Grand Rapids, Michigan: William B. Eerdman Publishing Company, 2001.

House, Paul R. Old Testament Theology. Downers Grove, Illinois: InterVarsity Press, 1998.

Kaiser, Jr., Walter C. Toward an Old Testament Theology. Grand Rapids, Michigan:Zondervan Publishing House, 1978.

Lee, Han Young. From History to Narrative Hermeneutics. New York: Peter Lang Publishing Inc., 200.

Payne, J. Barton. The Theology of the Older Testament. Grand Rapids, Michigan: Zondervan Publishing House, 1962.

Rad, Gerhard von. Old Testament Theology, vol. I. New York: Harper \& Row Publisher, 1962.

Robertson, O. Palmer. The Christ of the Covenants.Phillipsburg, New Jersey: Presbyterian and Reformed Publishing Co., 1980.

Sailhamer, John H. Introduction to Old Testament Theology: A Canonical Approach. Grand Rapids, Michigan: Zondervan Publishing House, 1995. 
Schmidt, W. H. "Theologie des AT vor und nach Gerhard von Rad," in Verkundingung und Forschung. Beiheft zur EvT, 17, Munich: 1972.

Trible, Phyllis. "Overture for a Feminist Biblical Theology," in The Flowering of Old Testament Theology: A Reader in Twentieth-Century Old Testament Theology, 1930 - 1990, ed. Ben C. Ollenburger, Elmer A. Martens, and Gerhard F. Hasel (Winona Lake, Ind.: Eisenbrauns, 1992.

Internet Sites

Lee, Han Young. Old Testament Theology, Class Note. Yangpyeong, Seoul:

ACTS, Spring Semester, 2009.

Lehman, Chester K. Nature and Method of Biblical Theology.

http://www.bibleviews.com/ot - chl.html

Liefeld, Walter L. "Unity and Diversity in the Two Testaments," Christian Brethren Review.

http://www.biblicalstudies.org.uk/pdf/cbr/unity_liefeld.pdf

What is Old Testament Theology? http://www.gotquestions.org/Old-

Testament-theology.html

Relationship between Old and New Testament.

http://en.wikipedia.org/wiki/Old testament 